\title{
The performance of first generation of domesticated javaean barb (Systomus orphoides) fry
}

\author{
Raden Roro Sri Pudji Sinarni Dewi ${ }^{1},{ }^{*}$ Irin Iriana Kusmini $^{1}$, Deni Radona $^{1}$, and Fera \\ Permata Puteri \\ ${ }^{1}$ Research Institute for Freshwater Aquaculture and Fisheries Extension, Jl Sempur No. 1 Bogor, \\ Indonesia
}

\begin{abstract}
The existence of native fish in Indonesian waters, especially in West Java, is under threat due to environmental damage. The domestication of javaean barb (Systomus orphoides) is directed to save the existence of this species and provide economic benefits for the aquaculture community. This study aims were to obtain information about the potential production of larvae and fry of javaean barb that was reared in ex-situ. The parameters observed were fecundity, fertilization rate, hatching rate, the survival rate of larvae, fry growth rate, feed conversion ratio, and fry survival rate. The results showed that javaean barb could be spawned ex-situ through induce breeding techniques. Fecundity was $96632 \pm 24012 \mathrm{eggs} / \mathrm{fish}$ with a fertilization rate of $98.3 \pm 1.50 \%$ and a hatching rate of $64.5 \pm 27.10 \%$. The survival rate of 3 days old larvae was $85.2 \pm 7.50 \%$. The growth rate of javaean barb fry was positive allometric. The weight-specific growth rate was $4.9 \pm 0.22 \%$ with an FCR of $1.7 \pm 0.28$ and survival rate of $89.3 \pm$ $4.16 \%$. The success of ex situ javaean barb seedling production opens opportunities for developing this species cultivation in the future.
\end{abstract}

\section{Introduction}

Javaean barb (Systomus orphoides) is a native fish in Indonesia that can be developed as an aquaculture commodity because it is liked by the local community, especially in West Java. Javaean barb has a higher protein content than silver barb and tilapia [1]. Some of the characteristics of javaean barb are the red color in the eye's iris, a little red in the operculum, and brown at the ends of all fins. In West Java, javaean barb or popularly known as beureum panon, live in the Citarum River. The existence of this fish in the Cirata reservoir is still found, but in the Citarum River, it isn't easy to find [2]. The javaean barb is included in the red category of threatened species [3]. Domestication of local fish is one of the efforts to diversify the cultivated species. In general, local fish is favored by people in certain areas due to historical/tradition. These cultural, or regional differences make the local fish an exceptional food of a particular site. For example, belida (featherback fish, Chitalalopis) in

\footnotetext{
*Corresponding author: sripudjisinarni@gmail.com
} 
Palembang, uceng (barred loach, Nemacheillus fasciatus) in central java, nilem (bonylip barb, Osteochilusvittatus) in West Java, baung (Asian redtail catfish, Hemibagrus nemurus) in South Sumatera, bilih (bilih fish, Mystacoleucus padangensis) in West Sumatra and others.

The efforts to domesticate javaean barb that has been carried out are through the reproductive approach $[4,5]$. Domestication is an effort to cultivate fish of natural origin into the controlled environment so that their breeding and feeding can be controlled and benefit humans [6]. In fish, domestication means that the entire life cycle of fish can take place in a culture condition starting from eggs, larvae, juveniles, and broodstock, so that management of broodstock, larvae, and juvenile is needed [7]. In the domestication process, several obstacles generally occur, including the availability of suitable food, slow growth, long maturation period, difficulty in spawning, and stress. Most domesticated species will show the plasticity of behavioral flexibility that can make them adapt to a cultural condition and in an environment that is different from their natural habitat [8]. The advantages of domestication are the production, reproduction of organisms, and their costs can be controlled [9].

The Research Institute for Freshwater Aquaculture and Fisheries Extension has collected javaean barb from several locations in West Java. Evaluation of the potential for fry production and growth has been carried out to determine the potential for this fish cultivation. The purpose of this study was to obtain information about the production potential of javaean barb larvae and fry that are reared in ex-situ.

\section{Methods}

\subsection{Time and location}

This research was carried out from October 2020 until March 2021. The research location was in Research Station for Fish Germplasm, Research Institute for freshwater Aquaculture and Fisheries Extension, Bogor, Indonesia.

\subsection{Larvae production}

Larvae were obtained from artificial spawning. The weight and length of female broodstock were $255.7 \pm 27.32 \mathrm{~g}$ and $23.4 \pm 0.92 \mathrm{~cm}$, and for male broodstocks were $144.7 \pm 12.66 \mathrm{~g}$ and $19.7 \pm 1.06 \mathrm{~cm}$. The female selection was made by cannulation. At the same time, the choice of male broodstock was made by pressing the abdomen towards the genitals to see the presence of cement/sperm. The female with egg diameter $>1.1 \mathrm{~mm}$ was separated for further transfer to the spawning tank. For spawning, we used six females and six males. Spawning was done artificially with the induce breeding method. The female and male were injected using the hormone LHRHa + dopamine at a $0.6 \mathrm{ml} / \mathrm{kg}$ BW dose. Eggs are ovulated after 1112 hours of injection at water temperature $28^{\circ} \mathrm{C}$. Fertilization was carried out externally in a plastic bowl. The eggs of javaean barb are sinking and non-adhesive. The fertilized eggs from different females were placed in an aquarium $(60 \times 40 \times 40 \mathrm{~cm})$. Observations of fertilization and hatching rate were conducted by taking embryo samples into a plastic bowl. Observations were done until the eggs hatched $100 \%$.

\subsection{Larvae rearing}

The javaean barb larvae rearing was carried out in an indoor hatchery. The larvae were kept in an aquarium measuring $60 \times 40 \times 40 \mathrm{~cm}$, equipped with aeration. Larvae started to be fed at the age of 3 days after the yolk was absorbed. The larvae were fed with egg yolk emulsion 
at 3-7 days combined with plankton during rearing. The plankton was given until the larvae were 13 days old. The feed was given in the form of a solution/suspension until the age of 20 days. After that, the larvae can be fed by powder feed. The powder feed has a protein content of $41 \%$. The feeding schedule during larval rearing can be seen in Table 1 . The feed was given three times a day. Larval rearing was carried out for one month until they became fry.

Table 1. The feeding schedule for javaean barb larvae for one month of rearing

\begin{tabular}{lllllll}
\hline \multicolumn{1}{c}{ Feed } & \multicolumn{6}{c}{ Age (day } \\
\cline { 2 - 7 } & 0 & 3 & 7 & 13 & 20 & 30 \\
\hline Chicken egg yolk emulsion & & & & & & \\
Plankton & & & & & & \\
Powder feed (suspension) & & & & & \\
Powder feed
\end{tabular}

\subsection{Fry rearing}

Fry rearing was carried out in an indoor hatchery for two months. The fiber tank size was 1 $\mathrm{m}^{3}$ equipped with aeration. The density was 1000 fish/tank or one fish/L. Fry was kept in 3 rearing tanks. The size of the fry was $2.36 \pm 0.48 \mathrm{~cm}$ in total length. The fry was fed by a commercial pellet (39\% protein content). Feed was given ad libitum three times a day.

\subsection{Parameter}

Parameters observed were fecundity, fertilization rate, hatching rate, larval survival, fry growth rate, feed conversion ratio, and fry survival. For measuring weight and length, 30 fishes were sampled every 30 days. The relationship of the length and weight of javaean barb reared for 60 days in a fiber tank was described by regression equation [16]. The data were analyzed descriptively to obtain information about the potential for fry production and the growth of the fry.

\section{Result}

In this study, the fecundity, fertilization rate, and hatching rate (Table 2) were relatively not different from previous research [5]. In the previous research, the fecundity was $245.5 \pm 35.3$ eggs/g, the fertilization rate was $100.0 \pm 0.0 \%$, and the hatching rate was $73.2 \pm 3.8 \%$ [5]. Compared with javaean barb in nature, the fecundity of the fish kept in controlled cultivation has a higher fecundity. The female broodstock in the wild at an average weight and length of $152.3 \mathrm{~g}$ and $17.1 \mathrm{~cm}$ have a fecundity of 20,924 eggs/fish or $137 \mathrm{eggs} / \mathrm{g}$ [2].

On day 3 , when the egg yolk was almost totally absorbed, and on day 7 , when the larvae started getting external food, the larval survival rate was relatively high (Table 2; Figure 1). The larval phase is critical in fish life, significantly when changing from intrinsic to extrinsic food. Selection of the correct type of feed, in terms of size and nutritional content, as well as rearing in optimal environmental conditions, is a determining factor for the success of larvae rearing [11]. 
Table 2. Reproduction of javaean barb that was spawned by induced breeding in controlled rearing

\begin{tabular}{lc}
\hline \multicolumn{1}{c}{ Parameter } & Value \\
\hline Absolute fecundity (eggs/fish) & $96.632 \pm 24.012$ \\
Relative fecundity (eggs/g) & $334 \pm 86$ \\
Fertilization rate (\%) & $98,3 \pm 1,50$ \\
Hatching rate (\%) & $64,5 \pm 27,10$ \\
The survival rate of 3 days post hatched (\%) & $85,2 \pm 7,50$ \\
The survival rate of 7 days post hatched (\%) & $78,9 \pm 7,63$ \\
\hline
\end{tabular}
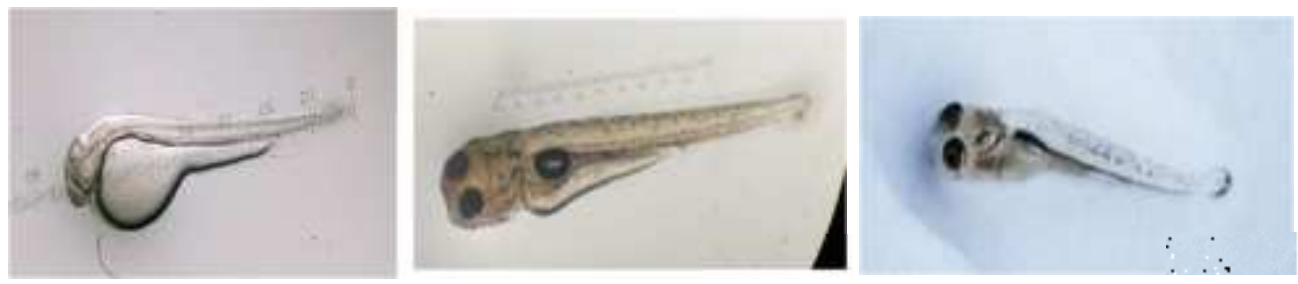

Fig. 1. The javaean barb larvae aged 0-, 3-, and 7-days post-hatch

The weight-specific growth rate of fry of javaean barb in the first generation was higher than that of the length-specific growth rate (Table 3 ). The javaean barb fry growth pattern was allometric ( + ) with a correlation value of $\mathrm{R}^{2}=99.9 \%$ (Fig 2). Likewise, the coefficient variance value was higher in the bodyweight than that of the length of the fry of javaean barb in the first generation. This fry growth rate pattern was similar to the growth pattern of asian redtail catfish [12]. This indicates that the influence of the environment was more significant on weight gain than the length. The feed conversion ratio of javaean barb in the frying phase was relatively higher than that of Asian redtail catfish, which was $1.58 \pm 0.02$ [12]. A feed conversion ratio is an indicator to measure the effectiveness of the feeding and the quality of feed [14].

Table 3. The growth, survival rate, and feed ratio conversion on javaean barb fryin the indoor hatchery for 60 days of rearing

\begin{tabular}{cc}
\hline Parameter & Value \\
\hline Initial weight $(\mathrm{g})$ & $0,2 \pm 0,17$ \\
Final weight $(\mathrm{g})$ & $3,6 \pm 0,49$ \\
Initial total length $(\mathrm{cm})$ & $2,4 \pm 0,48$ \\
Final total length (cm) & $6,1 \pm 0,18$ \\
Initial biomass (g) & $22,7 \pm 0,02$ \\
Final biomass (g) & $263,0 \pm 26,17$ \\
SGR of weight (\%) & $4,9 \pm 0,22$ \\
SGR of length (\%) & $1,6 \pm 0,05$ \\
CV of weight (\%) & 13,50 \\
CV of length (\%) & 2,96 \\
FCR & $1,7 \pm 0,28$ \\
SR (\%) & $89,3 \pm 4,16$ \\
\hline
\end{tabular}




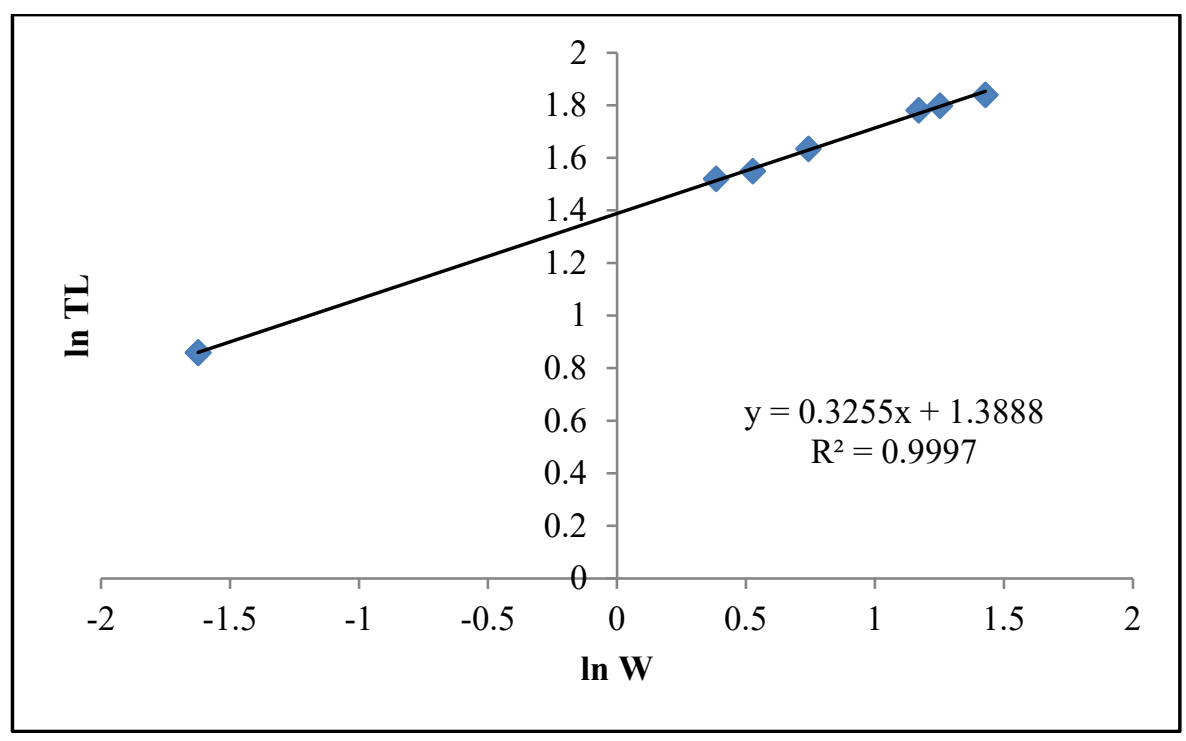

Fig. 2. The relationship of length and weight of javaean barb that was reared for 60 days in a fiber tank

\section{Discussion}

Javaean barb has been successfully spawned through the induce breeding technique [5]. The next step is to carry out controlled seedlings to increase the larvae and fry survival. In this research, the fecundity of javaean barb that was cultivated in a controlled environment and fed by artificial feed was higher than its natural. This indicates that the fish that were domesticated in controlled cultivation could adapt to a controlled environment outside their natural habitat (ex situ) and utilize nutrients in artificial feed for their reproductive development. Fecundity varies between species and individuals, depending on parental conditions such as size (length, weight, and age), genetics, food availability, and environmental factors [10].

Increasing the production of high-quality fry is the key to success in aquaculture. Although larvae can be produced in large numbers, the mortality rate is often high. The size of the fry produced varies, indicating a gap in knowledge regarding nutritional requirements and hatchery conditions [11]. In this study, the survival rate of fry was relatively high (Table 3). In some domesticated fish, such as Asian redtail catfish [12], domesticated fry has utilized artificial feed to have a relatively high survival rate. In addition, the relatively low stocking density of fish in this study was also thought to have a role in reducing stress in fish, thereby increasing the chances of high survival, as in the case with Asian redtail catfish [13]

Growth is an increase in length, weight, or volume in a specific time. Growth can be used as one of the indicators to evaluate the physiological conditions of individuals. Feed that has good nutrition is instrumental in maintaining survival and accelerating fish growth [15]. The growth pattern of javaean barb fry was allometric $(+)$, which indicates that the fish grow faster in weight than in length. This result was different from the previous research, which states that the growth of javaean barb in nature at a size of 87-174 $\mathrm{g}$ and a standard length between 115-191 mm is negative allometric, which indicates the increase in length of fish was faster than the increase in weight [2]. This difference was possible because this study was conducted on fish of $0.2-3.6 \mathrm{~g}$ or $2.4-6.1 \mathrm{~cm}$ in size so that the growth patterns could be different. 
Domestication will be considered synonymous with natural selection in a domestic environment [9]. The production of marketable fish begins with the stocking of fry or juveniles into a rearing environment that assures optimum and rapid growth to allow harvest in the shortest possible time. The fish farmer has to obtain an adequate number of young fish to meet his production goal. In this study, the success of javaean barb fry production opened the opportunity for its culture in the future.

\section{Conclusion}

The javaean barb that was reared in a controlled environment produced higher fecundity than its nature. The fecundity was $96,632 \pm 24,012 \mathrm{eggs} / \mathrm{fish}$, with a fertilization rate of $98.3 \pm$ $1.50 \%$ and a hatching rate of $64.5 \pm 27.10 \%$. The survival rate in the larval stage was $78.9 \pm$ $7.63 \%$. The fry growth rate is positive allometric, which indicates that growth of weight was faster than length. The weight-specific growth rate was $4.9 \pm 0.22 \%$ with an FCR of $1.7 \pm$ 0.28 and a survival rate of $89.3 \pm 4.16 \%$.

\section{Acknowledgment}

This research was funded by the DIPA of the Research Institute for Freshwater Aquaculture and Fisheries Extension in 2020. We want to thank Nurhidayat, S.P, M.Si, as the head of the research center for his support in this research.

\section{References}

1. S. Hadisusanto, S. Suryaningsih, Biota, 16, 2 (2011)

2. T. Herawati, A.Yustiati, A. Andriani, Pros. Sem. Nas. Ikan XIII (2014).

3. IUCN. Javaen Barb IUCN Red List of Threatened Species Version 2019. www.iucnredlist.com (2019)

4. W. Cahyanti, F. P. Putri, S. Sundari, A. H. Kristanto, J. Ris. Aku., 15, 3 (2020).

5. A. Iswantari, W. Cahyanti, F. P. Putri, D. A. Hedianto, V. A. Prakoso, A. H. Kristanto, IOP Conf. Series: Earth and Environ. Sci. 744 (2021).

6. F. Teletchea, P. Fontaine, Fish and Fisher., 15 (2014).

7. F. Teletchea, P. Fontaine, Aqua. Res., 42 (2011).

8. C. A. Driscoll, D.W. Macdonald, S. J. O’Brien, Proc. Natl. Acad. Sci. U.S.A, 106 (2009)

9. I. C. Liao, Y. S. Huang Ciheam, 47 (2000).

10. Z. A. Muchlisin, M. Musman, N. Fadli, M. N. Siti-Azizah, AACL Bioflux, 4, 3 (2011).

11. L. M. P. Valente, K. A. Moutou, L.E.C. Conceicao, S. Engrola, J. M. O. Fernandes, I. A. Johnston, Rev. in Aqua, 5 (Suppl. 1) (2013).

12. D. Radona, I. I. Kusmini, V. A. Prakoso, A. H. Kristanto, R. Fakhrurrazi, IOP Conf. Series: Earth and Environ. Sci. 348 (2019).

13. O. Z. Arifin, V. A. Prakoso, E. H. Suhud, J. Subagja, JAI, 15, 1 (2020)

14. O.M. Millamena, R.M. Colloso, F.P. Pascual, Nutrition in tropical aquaculture: essentials of fish nutrition, feeds, and feeding of tropical aquatic species (SEAFDEC Aquaculture Department, Tigbauan, 2002)

15. Y. Koniyo, Juliana, Biodiv, 19, 1 (2018)

16. M. I. Effendie, Metode Biologi Perikanan (In Bahasa Indonesia) (Dewi Sri, Bogor, 1979) 